Association for Information Systems

AIS Electronic Library (AISeL)

Winter 12-5-2005

\title{
The Critical Success Factors and Integrated Model for Implementing E-business in Taiwan's SMEs
}

Chen Te Fu

Yi Chen Lan

Follow this and additional works at: https://aisel.aisnet.org/iceb2005

This material is brought to you by the International Conference on Electronic Business (ICEB) at AIS Electronic Library (AISeL). It has been accepted for inclusion in ICEB 2005 Proceedings by an authorized administrator of AIS Electronic Library (AISeL). For more information, please contact elibrary@aisnet.org. 


\title{
The Critical Success Factors and Integrated Model for Implementing E-business in Taiwan's SMEs
}

\author{
Chen $\mathrm{Te} \mathrm{Fu} *$, Yi Chen Lan ** \\ * PhD Candidate, School of management, University of western Sydney \\ Lecturer, Cheng Shiu University, Taiwan \\ Email: phd2004_05@yahoo.com \\ ** Senior Lecturer, School of computing and IT, University of western Sydney \\ Email: y.lan@uws.edu.au
}

\begin{abstract}
Purpose - To date, identifying barriers and critical success factors (CSFs) and integrating business model in implementing e-business for SMEs have not been systematically investigated. Few existing studies have derived their CSFs and business model from large companies' perspectives and have not considered the needs of integration for smaller businesses. This paper is aimed to bridge this gap. Design/methodology/approach - Existing studies on CSFs and e-business model were reviewed and their limitations were identified. By integrating insights drawn from these studies as well as adding some new factors, the author proposed a set of 18 CSFs which is believed to be more useful for SMEs. The importance of the proposed CSFs was theoretically discussed and justified. In addition, a case study was conducted to evaluate the extent of success of this proposition. Findings - The overall results from the case study assessment were positive, thus reflecting the appropriateness of the proposed CSFs and integrated model. Practical implications - The set of CSFs and integrated model can act as a list of items and an easy to follow model for SMEs to address when adopting e-business. This helps to ensure that the essential issues and factors are covered during implementation. For academics, it provides a common language for them to discuss and study the factors crucial for the success of e-business in SMEs. Originality/value - This study is probably the first to provide an integrative perspective of CSFs and integrated model for implementing e-business in the SME sector. It gives valuable information, which hopefully will help this business sector to accomplish e-business visions.
\end{abstract}

Keywords: e-business, e-transition, CSFs, SMEs, ecommerce.

\section{Introduction}

Indisputably implementing and maintaining e-business for those large organizations is just another routine operation for their IT departments to ensure the business activities are performing efficiently. Nevertheless, small and mediumsized enterprises (SMEs) have far less resources and budgets to invest in IT enabled operations or the e-business vision.

According to the figure reported by the IDC Taiwan in
2003, there are 1,060,000 SMEs in Taiwan and just fewer than $40 \%$ of them have involved in e-business activities (having financial transactions through the Internet). This signifies that at least 636,000 SMEs have not engaged in ebusiness operations. However it does not mean that these SMEs have not considered the implementation of e-business operations. Most SMEs have recognised the need to change their current business processes to achieve the capability to engage in web based e-business activities. However, lacks of resources and budgets have prevented them from pursuing or continuing the e-business activities.

The key question this study tries to answer is what is the real factor that affects in implementing e-business operations in SMEs? This paper starts with surveying the e-business literature and identifying possible hurdles of transforming SMEs into e-capable (electronic capable) business operations. It is followed by categorising those factors or hurdles into two recognition phases. In addition to the hurdles, numbers of CSFs for SMEs to conduct e-business operations are identified and discussed. Through the literature study and investigation of various e-business transformation models, the authors have identified the components required for SMEs to transform into e-business operations successfully. A case study was introduced to verify the hurdles as well as the CSFs. This paper concludes with the proposition of an integrated e-business model to amalgamate all required components and provide ebusiness implement steps for SMEs.

\section{Literature Review}

The use of the Internet does not automatically mean placing a barrier between the firm and its customers and/or its suppliers. Revolve around inter-firm relationships. Many firms have invested in these relationships, sometimes over generations, and these relationships are key assets of the firm. The challenge is to leverage off these assets to a new level of competitiveness not to undermine them.

O'Keeffe (2001) outlines what the Internet can or cannot do by exposing seven myths. These are presented in Table 21 , the myths and realities of e-commerce and discussed below.

Proceedings of the Fifth International Conference on Electronic Business, Hong Kong, December 5-9, 2005, pp. 279 -28 9. 
Table 2-1: The myths and realities of e-commerce (O'Keeffe, 2001)

\begin{tabular}{|c|c|}
\hline The myths & The realities \\
\hline $\begin{array}{l}\text { 1. The Internet destroys } \\
\text { relationships }\end{array}$ & $\begin{array}{l}\text { Manage relationships as } \\
\text { intangible assets }\end{array}$ \\
\hline $\begin{array}{l}\text { 2. The Internet } \\
\text { disintermediates }\end{array}$ & Value is more transparent \\
\hline $\begin{array}{l}\text { 3. Simply reduce transaction } \\
\text { costs }\end{array}$ & Focus on process costs \\
\hline $\begin{array}{l}\text { 4. The Internet is about } \\
\text { public information }\end{array}$ & $\begin{array}{l}\text { Private information flows } \\
\text { can be enhanced }\end{array}$ \\
\hline $\begin{array}{l}\text { 5. A single hardware } \\
\text { purchase }\end{array}$ & $\begin{array}{l}\text { A dynamic relationship with } \\
\text { a solutions provider }\end{array}$ \\
\hline $\begin{array}{l}\text { 6. High risk and high } \\
\text { investment costs }\end{array}$ & $\begin{array}{l}\text { Amortised costs and low } \\
\text { risk trial adoption }\end{array}$ \\
\hline $\begin{array}{l}\text { 7. The Internet levels the } \\
\text { playing field }\end{array}$ & $\begin{array}{l}\text { The Internet leverages } \\
\text { investments in reputation } \\
\text { and relationship assets }\end{array}$ \\
\hline
\end{tabular}

The Internet is not about dis-intermediation but companies who do not add value or who have not invested in relationship or reputation assets are certainly under threat by the Internet infrastructure. The Internet infrastructure allows firms to manage the boundaries within the firm and between the firm and other players in the network to a new level of effectiveness and efficiency.

The e-commerce platform is not simply about adoption with current inefficiencies, but about re-engineering the total system. There are further opportunity savings as buyers and sellers can develop new accounts and invest in developing new relationships and strengthening current relationships. It is all about relationships as assets.

Hence, it is clear that the Internet is not about levelling the playing field, quite oppositely the Internet poses a competitive threat to those companies have lack of strategies or those with poor reputation or relationship assets. The Internet does provide the infrastructure for firms to unleash the power of past investments in their relationship and reputation assets and to develop these assets even further for long-term competitive advantage. The Internet provides a breakthrough technology in managing the boundaries of the firm both within the firm and with other firms in the network (O’Keeffe , 2001).

The literature in e-business strategy has addressed a wide spectrum of issues with regard to transforming an organization into e-business operations. (Mirchandani \& Motwani, 2001; Davy, 1998; Alexander, 1999). Furthermore, researchers have also discussed e-business adoption in various industries (Korchak \& Rodman, 2001), regions (Beveren \& Thomson, 2002; Gani, 2002; Walczuch et. al., 2000), and detailed technical steps involved in the transformation process (Eduard, 2001).

When analysing SMEs in e-business adoption, we have identified various factors that prevent them from using the full potential of the World Wide Web. The first contribution of this study is to identify the hurdles that affect the adoption of e-business operation in both pre- and post recognition phases. Furthermore, the second contribution of this study is to propose a set of critical successful factors for SMEs and an integrated model through a case study. The following sections outline the discussion of each factor within the associated phases and illustrate the development of ebusiness model.

According to Clayton (2000) more than $60 \%$ of the small companies do not have a plan for their business strategy. Although the remaining companies have such plans, there is no indication that e-business operation strategy has been incorporated. Lack of such incorporation or recognition of etransition strategy in business plans is considered as the major barrier in the success of e-business establishment. In the case studies conducted by the NOIE (National Office for the Information Economy) and Earnest and Young (2001), they have identified a number of factors that prevent SMEs moving to online operations, which are outlined as follows:

- Difficulties in finding reliable information that supports the e-business establishment;

- Difficulties in finding appropriate resources for a successful implementation;

- Difficulties of getting cost effective rates from ISP's (Internet Service Providers);

- Higher costs of payment gateways for online transactions; and

- Difficulties of finding and arranging suitable logistic solutions for product deliveries.

However, these factors merely represent the impediments in a single domain, which falls under post-recognition of e-transition strategy, and have no hurdles been discussed prior to the recognition. Hence, the factors need to be further categorised into two domains, namely "pre-recognition" and "post-recognition".

\section{1 Factors Affecting Success}

The e-transition recognition model introduced in Figure 2-1 brings all the hurdles in the pre-recognition and the postrecognition phases into a big picture. The proposed model is to be applied by SMEs to identify the bottlenecks and develop an appropriate practical plan, which will lead them to the success in e-transformation vision. The following sections explain the components of e-transition recognition model including recognition stage itself and pre- and postrecognition phases.

\section{II.1.1 Pre-Recognition Phase}

Based on our experience in working with SMEs in Taiwan in the e-transformation activities, we have identified the six factors in pre-recognition phase. In most situations these factors tend to strengthen each other making it further difficult for a small company to find solutions to the etransformation puzzle.

1. Resistance to change.

2. Nature of the business.

3. Lack of reliable resources to get the correct information. 
4. Lack of knowledge and myths associated with it.

5. Suppliers and customers are not geared e-commerce.

6. Difficulty in seeing direct ROI.

There has been some effort made to set up a mechanism to calculate the ROI of e-business initiatives (Edurad, 2001), but there is no one single formulae that can be easily applied to suite every SME.

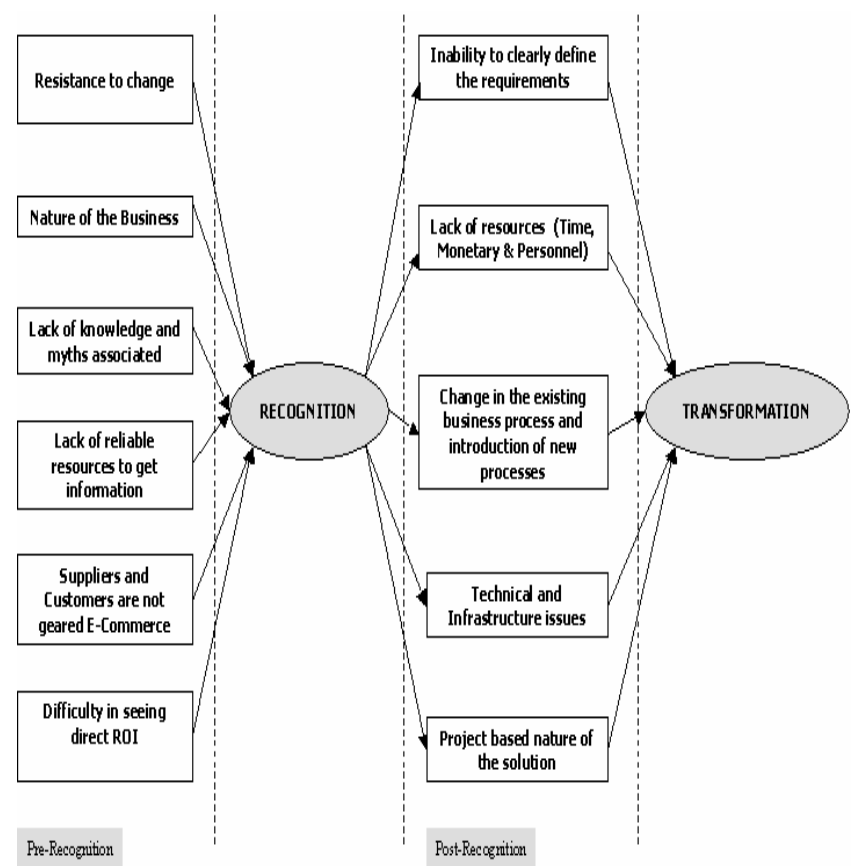

The factors in the Pre-Recognition phase converges into the biggest barrier the "Recognition" and after the recognition it diverges into the factors in the PostRecognition phase. In the case of a particular Micro Company it could be one or a combination of factors in both phases that might affect its E Transformation.

In the following section we will discuss these factors in detail with few real life examples.

Figure 2-1. E-transition recognition model

\section{1. 2 Post-Recognition Phase}

After successfully passing all the hurdles discussed above, SMEs would have recognized the need of e-transformation in order to be ahead in the competition. At this point they might have preliminary plans to carry out the transformation tasks.

We have identified five hurdles that might prevent a SME actually implementing the e-business operations. As in the pre-recognition phase, factors in the post-recognition phase also have impacts on each other, which strengthens its affect and prevent the e-transformation becoming a reality.

1. Inability to clearly define the requirements.

It is unclear as to what it means to the business community and even to the most of the web community. None of the above is considered as truly e-transformed organizations. Only when the internal information systems are fully converged with the external/online information systems the etransformation is achieved (Khandelwal et. al, 2004).

\section{Lack of resources.}

These resources are time, funds and personnel.

3. Change in the existing business process and introduction of new processes.

In case of a site where the customers can place on-line orders it would be important to have new business processes to handle orders and proper logistics to deliver goods. Inability to handle these changes or allocating resources to handle these new processes would result a failure in etransformation.

\section{Technical and Infrastructure problems.}

SMEs operate in remote areas where the IT and telecommunication infrastructures are not available for getting access to the Internet or services from ISPs.

5. Project based nature of transformation and maintenance.

Most SMEs without in-house IT staff would need to outsource the development of e-business operations. Generally these types of activities are carried out in a project-based format where the project ends with the handing over.

\section{2 Factors Achieving Success}

Identifying the CSFs (critical success factors) allows a firm to realize the full advantages of achieving e-business solutions. We have highlighted six CSFs based on the literature and our experience as follows.

- The first CSF is to identify a suitable vision for the firm. This vision is important as it provides everyone in the organization with the future direction.

- The second CSF is that the firm must also have an ebusiness champion who will help make the vision a reality. This person must be a strong leader who owns the etransformation process at a company, and must also be visual, energetic, and passionate about the transformation.

- The third CSF is the creation of a healthy company culture. With this energized corporate structure, all employees will be involved in the corporate decisionmaking process.

- The fourth CSF is the development of a plan to achieve the e-transformation (Marzulli, 2000). This plan needs to be in document form and include milestones and metrics that describe the e-transformation journey. The e-business champion and senior management should review this plan regularly.

- The fifth CSF deals with corporate communication (Marzulli, 2000). A rigorous communication strategy must 
be implemented within the firm. This allows the organization to receive more feedback from constituents. This is imperative when e-business solutions are complex.

- The sixth CSF for an e-business firm is its ability to create flexible e-business solutions. This will allow the firm to grow in the future as well as personalize to various suppliers and customers.

If an organization can observe all of the above critical success factors, the expected e-business solutions can be achieved.

Furthermore, KITE identified nine CSFs relevant to the competitive performance of small businesses entering the ecommerce market. This list took as its starting point a number of CSFs that were suggested to us by one of the reviewers (van Rijsbergen, 1998). The original list was expanded and refined in the light of experience with the Web Corporation in KITE. A further two factors (commitment and partnership) were derived from the interviews with the best practice sample. The final list of 11 factors is shown in Table 2-2.

Table 2-2: Critical success factors (Jeffcoate, Chappell, and Feindt, 2002)

\begin{tabular}{|c|c|}
\hline CSF & Description \\
\hline Content & $\begin{array}{l}\text { The effective presentation of a } \\
\text { product or service offered over the } \\
\text { Internet }\end{array}$ \\
\hline Convenience & $\begin{array}{l}\text { The usability of the Web site for the } \\
\text { purpose for which it was designed }\end{array}$ \\
\hline Control & $\begin{array}{l}\text { The extent to which organizations } \\
\text { have defined processes that they can } \\
\text { manage }\end{array}$ \\
\hline Interaction & $\begin{array}{l}\text { The means of relationship building } \\
\text { with individual customers }\end{array}$ \\
\hline Community & $\begin{array}{l}\text { The means of relationship building } \\
\text { with groups of like-minded } \\
\text { individuals or organizations }\end{array}$ \\
\hline Price sensitivity & $\begin{array}{l}\text { The sensitivity of a product or } \\
\text { service to price competition on the } \\
\text { Internet }\end{array}$ \\
\hline Brand image & $\begin{array}{l}\text { The ability to build up a brand name } \\
\text { for the e-commerce business, and its } \\
\text { products and services }\end{array}$ \\
\hline Commitment & $\begin{array}{l}\text { A strong motivation for using the } \\
\text { Internet and the will to innovate }\end{array}$ \\
\hline Partnership & $\begin{array}{l}\text { The extent to which an e-commerce } \\
\text { venture uses partnerships (value } \\
\text { chain relationships) to leverage } \\
\text { Internet presence and expand its } \\
\text { business }\end{array}$ \\
\hline $\begin{array}{l}\text { Process } \\
\text { improvement }\end{array}$ & $\begin{array}{l}\text { The extent to which companies can } \\
\text { change and automate business } \\
\text { processes }\end{array}$ \\
\hline Integration & $\begin{array}{l}\text { The provision of links between } \\
\text { underlying IT systems in support of } \\
\text { partnership and process improvement }\end{array}$ \\
\hline
\end{tabular}

By eliminating repetitions, a core group of recommended actions for each CSF was derived. These were grouped by category so that Web Corporation could focus on the recommendations applicable to them.

\section{2. 2 The New Stage by Stage of CSFs}

By integrating the abovementioned factors, the authors propose a more comprehensive model of 15 factors and separate into three stages for implementing e-business in SMEs (see Table 2-3).

Table 2-3: A set of new stage by stage of CSFs

\begin{tabular}{|c|c|}
\hline Stage & CSFs \\
\hline Start-up phase & $\begin{array}{l}\text { Vision, company culture, a plan to } \\
\text { achieve the e-transformation, } \\
\text { commitment, content, price } \\
\text { sensitivity and convenience }\end{array}$ \\
\hline $\begin{array}{l}\text { Growth/transition } \\
\text { phase }\end{array}$ & $\begin{array}{l}\text { e-business champion (leaderships), } \\
\text { Corporate communication, control, } \\
\text { interaction, community and brand } \\
\text { image }\end{array}$ \\
\hline Maturity phase & $\begin{array}{l}\text { Ability to create flexible e-business } \\
\text { solutions, partnership, process } \\
\text { improvement and integration, } \\
\text { strategic positioning in KVC, } \\
\text { mobilization }\end{array}$ \\
\hline
\end{tabular}

In order to achieve the success in e-business transition the above CSFs could be segmented into three stages. Once an e-business has determined its strategy and stage of development, it can identify the CSFs that are applicable to it.

It is necessary through "stage by stage" to build an optimal model in implementing e-business When SMEs develop their e-business model because they are lacked of resources, personnel and monetary. Besides, an optimal business model could help firms to form sustainable competitive advantage because unique business model is hard to be imitated by competitors. Therefore, referring above CSFs, the study further reviews a stage model which can describe the logical evolution of e-commerce involving different stages of development, each stage being better in some sense than the previous stage, can be useful in providing a roadmap for improvement to companies. A stage model, we believe, can do this.

\section{2. 2 A Stage Model for E-commerce Development}

To achieve the goal of becoming an "e-SME", the Local Futures Group (2001, cited in Dixon et al., 2002) suggest that firms must cross two digital divides:

1.The first divide involves acquiring basic ICT skills and technology to operate e-mail and simple brochure Web sites.

2.The second digital divide is the threshold to e-business proper, and requires advanced technology and IT skills (including $\mathrm{R} \& \mathrm{D}$ ) and a wide range of specialist business skills and knowledge in areas such as management, strategy 
and marketing.

It implies that all SMEs have the need and opportunity to follow one prescribed course; with the implication that not to finish the course (cross the divides) is some kind of failure.

Furthermore, Subba and Glenn (2003) proposed that ecommerce development takes place in four stages (see Figure 2-2):

\section{Stages of E-Commerce Development and their characteristics}

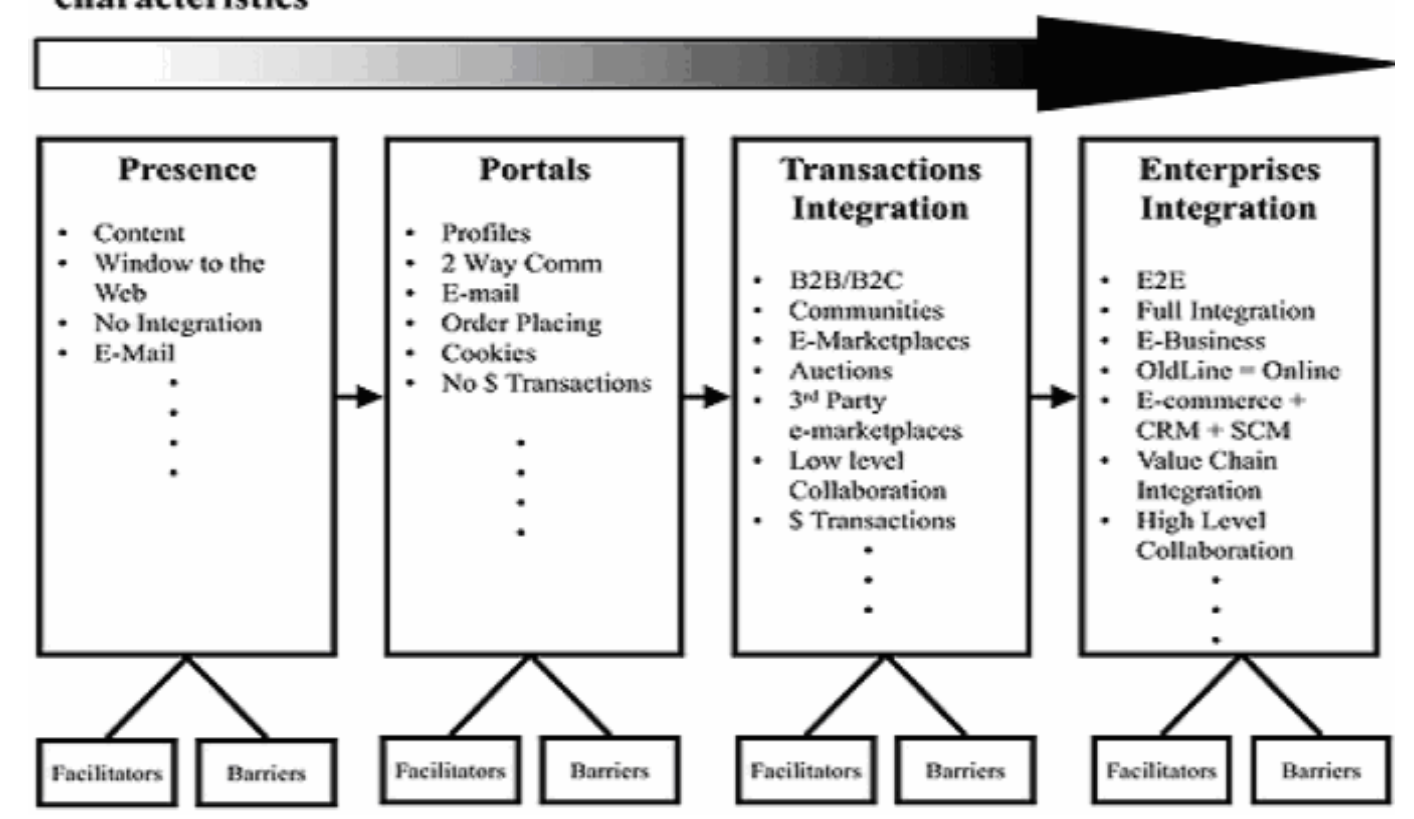

Figure 2-2: A stage model for e-commerce development (Subba and Glenn, 2003)

The four stages are listed below:

(1) Presence (no integration).

(2) Portals (no \$ transaction).

(3) Transactions integration (low level collaboration).

(4) Enterprises integration (value chain integration and high level collaboration).

The study argued that SMEs could start in any stage of abovementioned, it depends on their resource, personnel, technological support, and so on. The model allows for a company to enter at any stage. It is not necessary that a company begins at the presence stage and then progresses through subsequent stages although the stage model as proposed appears sequential. It depends on the degree of increasing awareness for technology and e-commerce. The point is what factors promote and what factors inhibit or retard e-commerce development and implementation at a particular stage. S. Subba, Glenn, Carlo A., (2003) call these facilitators and barriers to e-commerce development and implementation. If the primary impact of the factor is internal and within the control of the SME, they classify it as a facilitator since the enterprise can improve its readiness for a given stage. On the other hand, if the primary impact of the factor is beyond the control of the enterprise they have generally classified them as barriers.

\section{2. 3 Information Value Chain}

In e-commerce operations, information is not viewed as a by-product of the strategic activities performed around the physical value chain. It is viewed rather to play a strategic role in itself. For this reason, strategic activities in the virtual value chain are performed in conjunction with information. This is well explained by Rayport and Sviokla (1995), with the concept of a "virtual value chain".

According to Rayport and Sviokla, a virtual value chain consists of "gathering, organizing, selecting, synthesizing, and distributing of information". Hence, it becomes imperative that businesses amalgamate virtual chain activities with physical activities to become fully integrated business operations to offer customized products and services, as shown in Figure 2-4. While virtual value chain enables companies to access information and finalise transactions, physical value chain ensures the order fulfilment and delivery of products and services to the customers (Rayport and Sviokla, 1995).

To be brief, the success e-commerce operations will depend upon the ways the physical value chain and the virtual value chain activities are matched and integrated into an information value chain.

It is obvious that merely integrating virtual value chain with physical value chain does not guarantee organizations in sustaining the competitive challenges. To take one step further, the optimal approach is for an organization to create its knowledge assets as knowledge turns into the main 
source of competitive advantage (Miles, 1993; Miles et al., 1994). The following section reviews knowledge value chain and proposes the convergence of information and knowledge value chains.

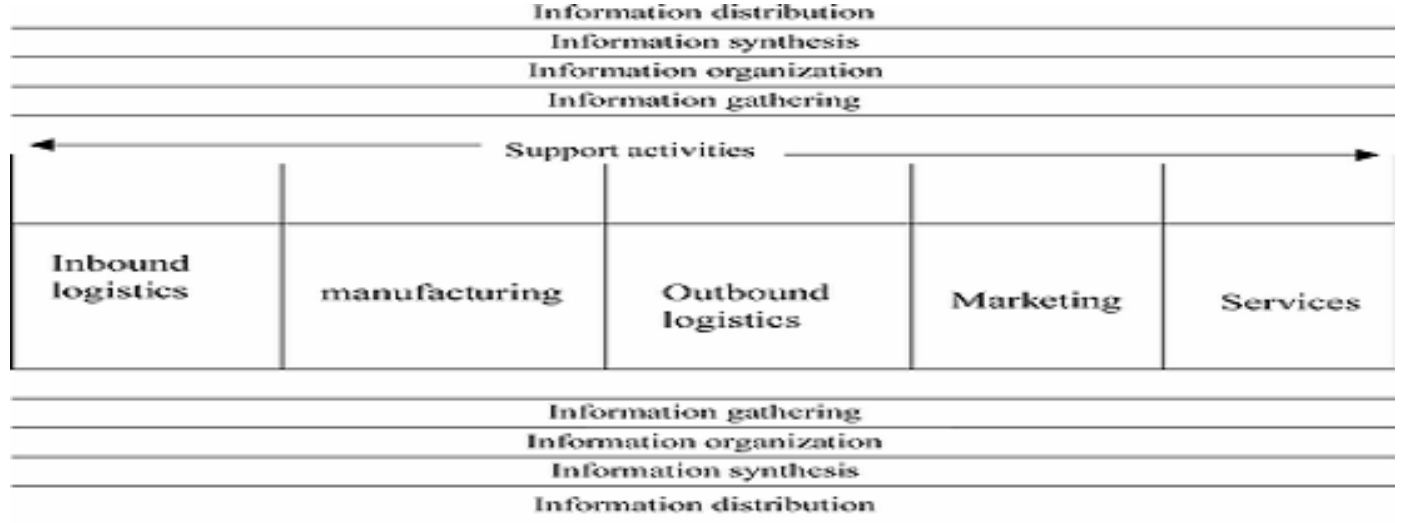

Source: Adapted from Porter (1985) and Rayport and Sviokla (1995)

Figure 2-4: Integrated framework of virtual chain activities with physical activities (Rayport and Sviokla, 1995)

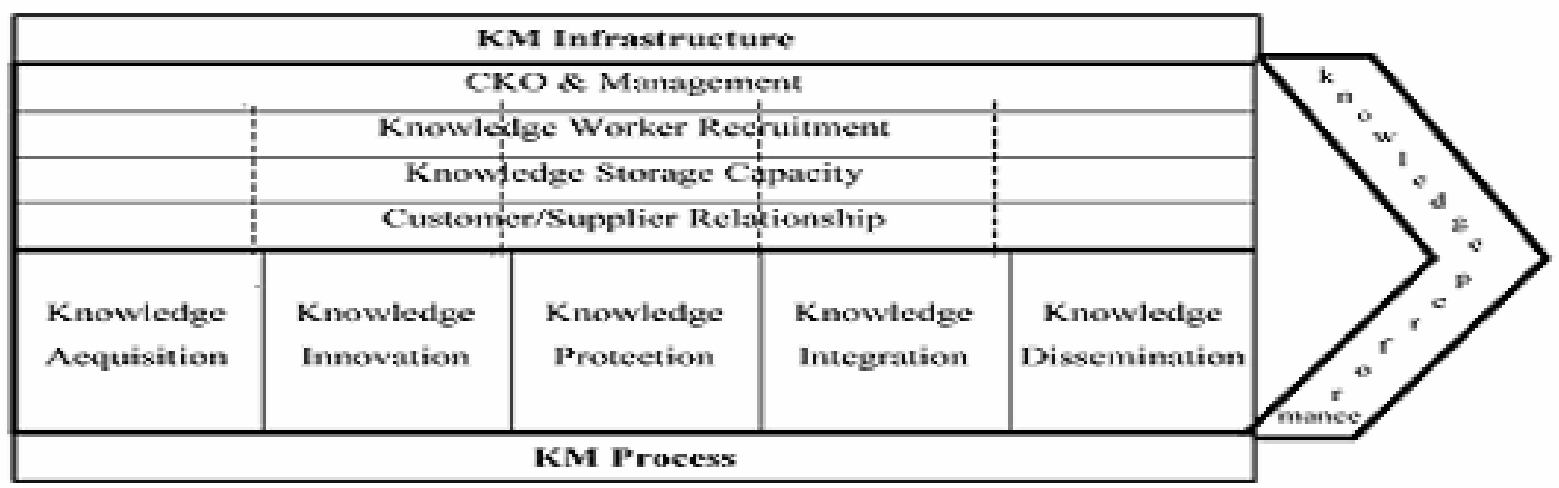

Figure 2-5: Knowledge value chain mode (Lee and Yang, 2000)

\section{2. 4 Knowledge Value Chain}

Employing Porter's value chain analysis approach (Porter, 1985), Lee and Yang (2000) proposed a knowledge value chain model (figure 2-5).

These infrastructure components and activities are the building blocks by which a corporation creates a product or provides service valuable to its customers.

\section{2. 5 The Integration of KVC and Business Value Chain}

As the value chain itself implies, each element of activity can create value and then all the value flows to the endpoint of the business value chain and joins together, forming the overall value of business, which is usually expressed as a margin (see Figure 2-6).

According this model, Lee and Yang (2000) proposed that the added value comes from the competence of element activity itself, which in turn comes from specific sub-KVC of itself, sub-KVC in inbound logistics (IL) operations (OP), outbound logistics (OL), marketing and sales (MS), and service (SE) activity enables business to gain the competence, and then the added value follows. Finally, all the sub-KVCs are integrated together into the whole KVC. In the process of knowledge integration, the competence of knowledge infrastructure is gradually forming. In the end, corporation competence follows KVC. By analyzing the above, Lee and Yang (2000) note that competence is after all the measurement of each sub-KVC. KM is a process that transforms information into knowledge, it is suggested that competitive advantage grows out of the way corporations organize and perform discrete activities in the knowledge value chain, which should be measured by the core competence of the corporation.

The characteristics of the enterprises integration stage include all e-commerce and non e-commerce aspects of the enterprise. At this stage they become melted together to a single system that serves all the needs of the enterprise. 


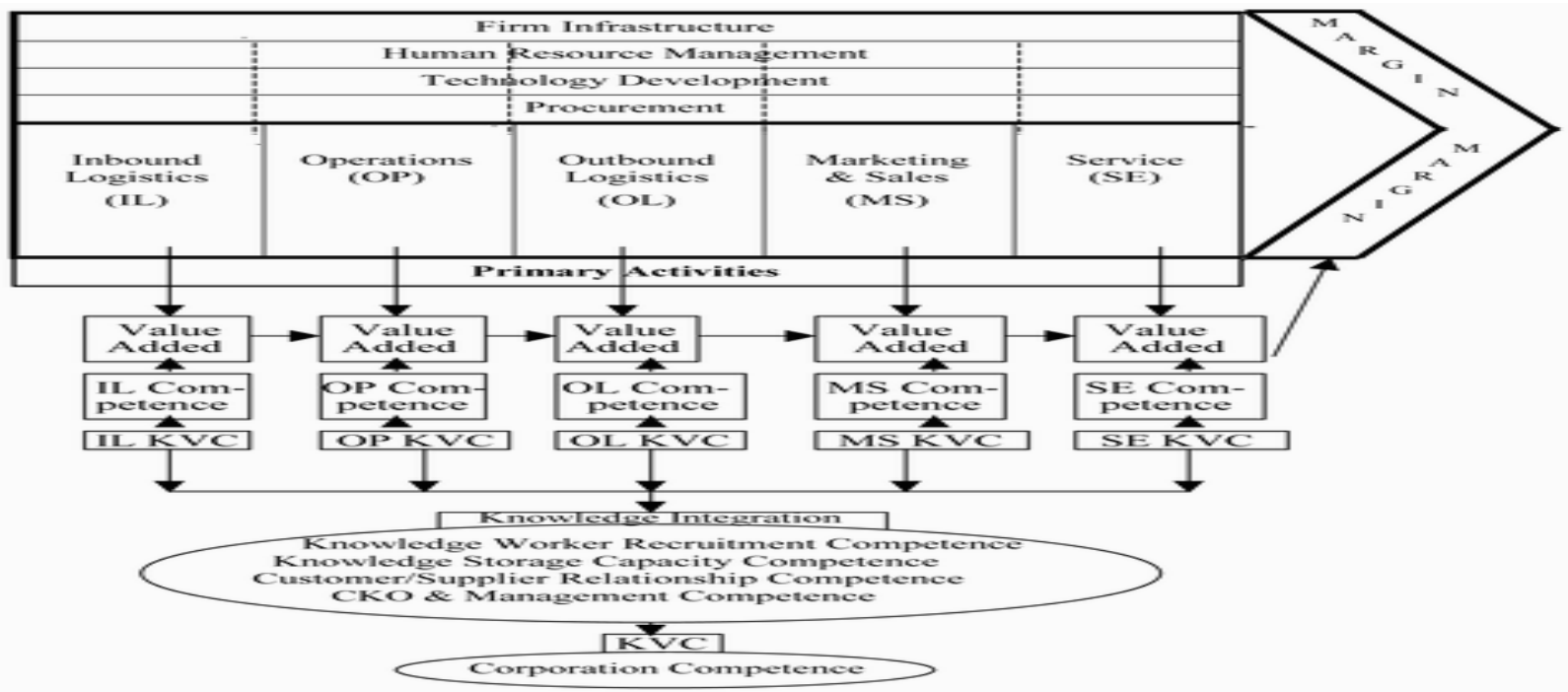

Figure 2-6: Relationship between business value chain and KVC

Source: Lee and Yang (2000)

\section{2. 6 EAI (Enterprises Application Integration)}

Successful players in the EAI stage will be able to distinguish themselves if they:

- Intimately understand their partners' current and future/strategic needs.

- Work proactively with their partners to create solutions that address these needs.

- Use information sharing; and

- Have long-term contracts (Lacerra et al., 1999; Krause et al., 1998).

It is argued that significant opportunities for improvement often lie at the interfaces between the various supply chain member organizations (Handfield and Nichols, 1999). Whether an order is initiated by a Web-based customer or a mail order customer does not matter. At this EAI stage the ecommerce departments disappear and all business processes are fully integrated across internal systems and external participants (suppliers, business partners, and customers).

\section{2. 7 K-Business}

While e-business gives us new access, exchange, and sales opportunities relative to information, k-business turns knowledge assets within a system into products, services, and profits. For e-business moves up to k-business, David Skyrme (2001) proposed ten Ps offer tips on online marketing that emphasize positioning, packaging, portals, pathways, pages, personalization, progression, payments, processes, and performance.

\section{2.8 M-Business}

A few years thereafter, Microsoft amended its statement to "empower people through great software, anytime, any place on any device." Being digital is out, being mobile is in. On November 21, 2002, when The Economist released its story on "Computing's new shape," the cover page featured a Nokia phone, not a Microsoft pocket PC. In The Freedom Economy, Peter G.W. Keen and Ron Mackintosh portray the "mCommerce edge in the Era of the Wireless Internet." Just as personal computers and the Internet have changed the landscape of ecommerce, the authors argue, mCommerce will continue to extend the way organizations conduct business, while changing the relationships between companies, customers, suppliers, and partners. To them, mobility means freedom, which creates choice and, thereby, value. The key areas for expanding value through mCommerce are customer relationships, logistics, and knowledge mobilization, or intellectual capital.

In Beyond Mobile, a trio of Kairos Futures' consultants (Mats Lindgren, Jörgen Jedbratt, and Erika Svensson) take the mobilization of many businesses and organizations as a given. They focus on the human aspects of mobile technology, exploring the ways that people will work and communicate in the mobile marketplace. Their bold future scenarios extend to the year 2007. According to Ravi Kalakota and Marcia Robinson, the mobile Internet is transforming employee, supply chain, and customer interaction, and providing new innovation, cost-reduction, and revenue opportunities. Their M-Business shows how to reposition and develop business processes and enterprise applications to take full advantage of the mobile business wave that is portrayed as compelling and complex, even if its value is needlessly inflated ("and overtaking your organization even as you read these words)". The gurus of IT-driven e-commerce business guides explore wireless revolution from a business perspective. They introduce strategies that can be exploited to adapt from tethered, PCcentric models to mobile, person-centric techniques and strategies. Claiming to focus on the bottom line, the authors explain how senior and financial managers can plan for and differentiate m-business investments. 


\section{3 Research Propositions}

The aim of above review was to generate a series of exploratory research propositions relating to the barriers and CSFs for SMEs develop e-business activities while to embrace the technology and technique. The propositions generated follow, and a fuller explanation will be obtained through following case study.

P1. The first stage of E-business start-up is to identify barrier to critical successful factors for transforming to e-business.

P2. After transform successfully, the second stage is to integrate virtual and physical value chain to form an information value chain for unleashing the power of information and relationship assets.

P3. The third stage is to integrate information and knowledge value chain, each element of activity can create value and then all the value flows to the endpoint of the business value chain and joins together, forming the overall value of business, competitive advantage grows out of the way corporations organize and perform discrete activities in the knowledge value chain.

P4. The fifth stage is to integrate information and knowledge value chain to k-business to create knowledge assets.

P5. The sixth stage is through EAI to integrate all systems to achieve sustainable competitive advantage.

\section{Methodology}

This paper adopts a case study to assess actual barriers and CSFs to the decision to implement an e-business strategy in the context of this particular SME. The completed questionnaire, company reports/industry-specific newsletters and a depth interview created an established chain of evidence.

Based on "grounded theory" the task of the researcher is to appreciate the different constructions and meanings that people place upon their experiences, rather than searching for external causes and fundamental laws to explain their behaviour. As Jones (1987) comments, grounded theory works because:

Rather than forcing data within logico-deductively derived assumptions and categories, research should be used to generate grounded theory that "fits" and "works" because it is derived from the concepts and categories used by social actors themselves to interpret and organise their worlds.

In SMEs most business decision-making is made by the owner-manager, therefore this person became the subject of an in-depth interview. The depth interview used the unstructured "tell me about it" approach to facilitate an open, flexible, illuminating way to study the complex, dynamic interactive situations such as management e-business decision making, providing:

The opportunity for the researcher to probe deeply to uncover new clues, open up new dimensions of a problem and to secure vivid accurate accounts that are based on "personal experience" (Burgess, 1982; Easterby-Smith et al., 1995).

\section{The Case Study}

The subject of the case study was a private firm operating in the IT industry sector in Taiwan since 1987. During the ensuing period it has steadily established itself as a specialist provider of a comprehensive IC design service, the supply and fitting of new and replacement layout products of computer motherboard, which include various interface cards. From this perspective, the nature of the service is highly tangible, highly customised and is available on a knowledge-based basis by skilled people.

It is a simply structured organization with 12 direct employees carrying out all responsibilities for day-to-day operations and resting with the managing director. Although locally focused, the company's main objective over the next five years was to expand the business operations in the global markets. Their customers include computer motherboard industries, which generates approximately 80 per cent of their business, and their customers almost implement business to business ( 80 per cent) and business to consumer (20 per cent) operations.

\section{Internal "e" enablers}

Fitting into the theme of "awareness" and potential opportunities, from the completed questionnaire the authors were able to deduce that the owner agrees that having electronic mail and a Web site is important for the business. Furthermore the owner perceived that e-commerce will become increasingly important to the company in the future. "Access" to Web-based communications is supported by an ADSL broadband connection to the Internet. The company has taken the initial step to establish its web "presence" and having their "virtual door" opened in September 1995.

\section{Internet commerce usage}

In relation to "actual" usage the owner/ managing director explains that:

"I am not concerned about cutting costs and it was not my intention to operate the business purely in the Internet platform, and it was just another way to advertise my service offering."

The owner did not perceive that having a Web site could lower costs for the business, but did in fact view his ebusiness decision as an added expense in the short term. The primary e-business objective is to promote the organization's name and intent, and provide potential customers with information on the service/product offering. In relation to ebusiness operations, the company was unsure of how much business was initiated by e-mail or its Web site. However, with an extremely low-level (basic) Web site it may be suggested that there may be limited e-business success. It is a static one-page information-based Web site (page) that gives the visitor details of company location, introduction of products and services and a brief history (five lines) about 
the company. There is, however, a contact facility (an online form) to enable contact with the company. At the time of the interview the owner had no plans to improve the sophistication/functionality of the Web site.

\section{The "real" barriers}

The dynamic environment that is synonymous with ebusiness is a similar environment in which this company operates where complex micro issues prevent further development in e-business. It becomes evident that the ebusiness processes of this small business are at present isolated from the strategic e-business context where the ability to implement full-blown e-business is for this company impeded by various obstacles. Each day the owner is more preoccupied with "fire-fighting to realize and fulfil customer orders, where there is a heavy reliance on face-toface contact". The owner also perceives a lack of the suitability of Internet commerce for business purposes:

"Our service offering is highly tangible and is not really suited to the e-business environment."

This comment would support the e-services literature where the potential for electronic selling of services/products on the Internet is positively correlated with intangibility. (Lovelock et al., 1999; De-Kare Silver, 2000). The "real" issues of limited resources were cited as inhibiting e-business activities where the owner stated:

"We do not have the resources (manpower and financial), or technical capabilities to manage the demands that online orders may generate ... there is also the issue of distribution."

The owner admits that he is not technically adept and the person responsible for all the administrative duties already had a huge workload to handle each day. Consequently, although this SME has taken an initial step towards ebusiness, the barriers to full-blown implementation relate to:

- Lack of senior management support/enthusiasm;

- $\quad$ Lack of skills among the employees;

- Lack of resources; and

- A lack of awareness of the benefits of e-commerce for the business.

Furthermore the high level of tangibility of the service/product mix is viewed as one of the major impediments to future utilization of Internet commerce by this particular small business. The "ideal" factors identified by Daniel and Myers (2001) as most important for ebusiness adoption (senior management support, a staged implementation and a clear understanding of the benefits) are missing from the strategic "e" context of this particular SME.

To date there has been no indication of advancement through the stages of e-business growth to maturity. Subsequently, it is suggested that the e-business decision was a natural reaction (as opposed to being proactive) to much of the hype that has surrounded Internet commerce adoption, rather than any pre-conceived ideas about the benefits for the business, where this particular small business has taken a less than risky approach in their ebusiness decision.

To reiterate the aforementioned observation made by PricewaterhouseCoopers (1999):

"Often SMEs equate having a Web site with electronic commerce. They set it up and it sits there as a reminder of their failure."

The inherent lack of strategic emphasis in the e-business strategy of this small business makes this comment extremely pertinent. Perhaps justified by the fact that being at the experimental/informational stage of its development, the e-business objectives of this particular firm are being fulfilled, using the medium purely as a promotional tool. Consequently they have become a "virtual" statistic ... (whether skewed or not), viewed "as something justified by a univocal, irresistible 'progress"' (Winner, 1995).

\section{E-business implementation steps}

Before implementing an e-business solution, a firm must first identify its capability of handling an e-business solution. In relation to e-business implementing steps the owner indicated five major concerns on preparing e-business, they are:

1. Does every employee can use email to communicate with colleagues and customers?

2. Can the website achieve advertisement effects to promote the company's name and intent?

3. Can the website provide electronic transaction information for customers and suppliers and recommend potential customers with information on the service/product offering?

4. Do the firm and its suppliers use universal identifiers, codes and definitions to identify products and procedures within its electronic documents?

5. Does the firm link virtual and physical value chain to leverage the power of information and relationships assets?

Answers of most of these questions are positive, and the firm is ready for e-business implementation.

\section{An Integrated SMe-Business Model}

Through above literature review and case study discussions, the authors proposed an integrated SMe-business model to be an easy to follow framework for SMEs pursuing ebusiness operations as Figure 5-1.

Firstly, the study through e-transition model (etransformation) to overcome barriers and achieve critical successful factors in e-business and therefore to the integration of the physical and the virtual value chain (create channel relationships and relationships assets). Secondly, to further integrate with knowledge value chain (create knowledge assets) to achieve k-business (knowledge business) (David Skyrme, 2001). Through k-business, SMEs can integrate internal and external information and knowledge sources to create value. 
Moreover, the model through e-CRM to link with customer (create customer relationships assets) and through e-supply chain to link with suppliers (create supplier relationships assets). Finally, use EAI (Enterprises Application Integration) to integrate all of information and knowledge systems. EAI refers to the complete integration of business processes to the extent that old-line business is indistinguishable from online business (Subba and Glenn, 2003).

This level of integration involves high levels of collaboration between customers and suppliers. Enterprises integration includes full integration of B2B and B2C business including value chain integration. This level of integration utilizes the e-commerce systems to manage customer relationships (CRM) and the supply chain (SCM). This level of integration is e-commerce+CRM+SCM. This stage is somewhat of an ideal concept for the "e-world" environment. Many of the requirements of this stage still have technology problems and over-whelming integration issues for SMEs.

In summary, the study through case study and literature support, proposed two more items: strategic positioning in KVC and mobilization/communication to transform ebusiness to SMe-business (Strategic k-business $+\mathrm{m}$ business + e-business) for smaller and medium-sized enterprises. This model can help firms to create value, relationship, information and knowledge assets, integrate internal and external resources and to achieve competitive advantage in the future development of e-business.

\section{E-business implementation steps}

It is necessary for an organization to carry out its own processes toward e-business solutions. A number of organizations have named a chief e-business officer to help coordinate e-business initiatives. This setting allows for centralized control of e-business across an organization, thus resulting in a greater efficiency. Companies must be cautious when they start e-business initiatives; this attitude would help firms quickly move to real-time processes (Karpinski, 1999). However, the speed of implementing these strategies has inspired strategic working alliances across a broad range of industries. This has been demonstrated through the alliances that have occurred between infrastructure organizations and Web boutiques.

Firms implementing e-business solutions should recognize the challenges that face their organizations. First, they should comprehend the dot-com advantage. This occurs as a result of clients/customers' preference for dealing with what they know and trust. This situation is often called the click-and-mortar integration; it occurs not only to the customers, but also to the suppliers. Another challenge is about catching the marketplace rules. That is, the Web will support the supply chain more than ever. The third challenge is that customers should be dealt with first. A quality ebusiness solution, while being electronic and integrative, should improve connectivity, knowledge management, and performance. It thus improves the efficiency of the firms.
The study identified seven steps to implement a successful e-business solution. Specifically, they are:

1. Set a vision: start from top-down. The executives in the organization must embrace the e-business initiative. A company must recognize that the e-business functionality is a business project instead of a technical task.

2. Recognize up to date: The firm must ignore all of its old ideas and rules on how business is operated and develop total new ways to conduct business. Especially what are their barriers and CSFs to implement e-business.

3. Know your markets: The firm's brand identity, customers, competition, and supply chain should be analyzed in the "know your market" phase.

4. Link: The firm must link virtual and physical value chain to form an information value chain, this way can leveraging the power of information and relationships assets.

5. Positioning: Strategic positioning what role the company in e-business and knowledge value chain will act.

6. Integrate: The firm must through EAI to integrate all various corporate systems then "create" its e-business solutions.

7. Evaluate and update anytime: The firm must modify its e-business solution anytime as speed and innovation are the keys to the e-business world.

\section{Conclusion and Future Research}

\section{Conclusions}

The establishment of e-business operations presents tremendous challenges for maintenance in SMEs. The first stage of this paper is to identify barriers/factors through developing an e-transition recognition model and to find out critical successful factors through analysis of literature review. Secondly, summarize literatures review to construct a conceptual model and proposed some propositions. Finally, through case study to develop a new integrated model which can be employed by SMEs as the roadmap in their electronic business implementing process for transforming into digital business successfully and concludes with implement steps in e-business for practitioners and future researchers.

Through literature review, case study and discussion, the study due to the characteristics of SMEs to construct an integrated SMe-business model, CSFs and implement steps for SMEs. There is a lack of consistent, detailed research into how and why e-business is adopted. This paper has developed a holistic perspective which embraces sets of wider critical successful factors as well as more particular, integrated model which then contribute to the development of an e-business model and research propositions in order to address the situation.

\section{Recommendation}

The next stage in the research process will be the qualitative testing of the conceptual model. A series of in-depth interviews with managers of various sectors in SMEs will be 
carried out. Qualitative data analysis will allow for adjustment of the model before larger-scale quantitative testing using a structured postal survey instrument. It is also the intention of the authors to carry out comparative research in order to identify CSFs and evidence of best practice. As the e-business SME develops in international markets, one additional area might involve the investigation of the usefulness of current internationalization models.

\section{References}

[1]. Alexander A. (1999). Tuning small businesses for e-commerce. Accounting Technology, 15, 11, 48-57.

[2]. Anonymous (1999). APEC adopts electronic commerce models. Computer Dealer News, 15, 43, 23.

[3]. Australian Bureau of Statistics (2004). 8127.0 Characteristics of Small Business, Australia.

http://www.abs.gov.au/ausstats/abs@.nsf/b06660592430724fca2568b5 007b8619/e49e3b4dc3595c92ca2568a900139377!OpenDocument

[4]. Beveren J. and Thomson H. (2002). The use of electronic commerce by SMEs in Victoria, Australia. Journal of Small Business Management, $40,3,250-253$.

[5]. Clayton K. (2000). Microscope on micro business. Australian CPA, 70, 2, 46-47.

[6]. David J. Skyrme, (2001). Capitalizing on Knowledge - From Ebusiness to K-business, Reed Educational \& Professional Publishing/ Butterworth-Heinemann, Oxford.

[7]. Davy J. (1998). Electronic commerce: Is going online the right road for your company? Managing Office Technology, 43, 5, 20-23.

[8]. Edurad T. (2001). Adding Clicks to Bricks. Consulting to Management, $12,4,10-23$.
[9]. Gani H. (2002). Limited funds remain main hurdle for SMEs. Computimes Malaysia, July 25, 2002.

[10].Khandelwal, V., Ginige, A, Curry, J., Bajaj, K., Lan, Y., and Schmid, R. (2004). Information Technology in Western Sydney Status \& Potential: Survey 2003. University of Western Sydney.

[11].Korchak R. and Rodman R. (2001). eBusniess adoption among U.S. small manufacturers and the role of manufacturing extension. Economic Development Review, 17, 3, 20-25.

[12].Lee, Yang, (2000), “Knowledge value chain”, The Journal of Management Development, Volume 19 Number 9, pp. 783-794.

[13]. Michael O'Keeffe (2001), Supply Chain Management: An International Journal, Vol. 6 No. 1, pp. 12-15

[14]. Mirchandani D. and Motwani J. (2001). Understanding small business electronic commerce adoption: An empirical analysis. The Journal of Computer Information Systems, 41, 3, 70-73.

[15]. NOIE and Ernest \& Young (2001). Summary of 34 case studies of small business e- commerce Ventures. [Internet]. Available from : http://www.noie.gov.au/Projects/

CaseStudies/Ecommerce/PDF/report.pdf [Accessed 10 Sep 2002].

[16]. Ravi Kalakota, (2002). M-Business: The Race to Mobility, McGrawHill, New York.

[17]. Rayport, J, Sviokla, J, (1995). "Exploiting the virtual value chain", Harvard Business Review, 73, 6, 75-85.

[18]. Remko van Hoek (2001). 'E-supply chains - virtually non-existing', Supply Chain Management: An International Journal, Vol. 6, Issue 1, 8 p, pp. 21-28

[19].Rogers, E. (1995). Diffusion of Innovations. New York, Free Press.

[20].Subba S., and Glenn, A., (2003). Electronic commerce development in small and medium sized enterprises: A stage model and its implications, Business Process Management Journal, Volume 9, Number 1, pp. 11-32.

[21]. Walczuch R., Braven G., and Lundgren H. (2000). Internet adoption barriers for small firms in The Netherlands. European Management Journal, 18, 5, 561-572.

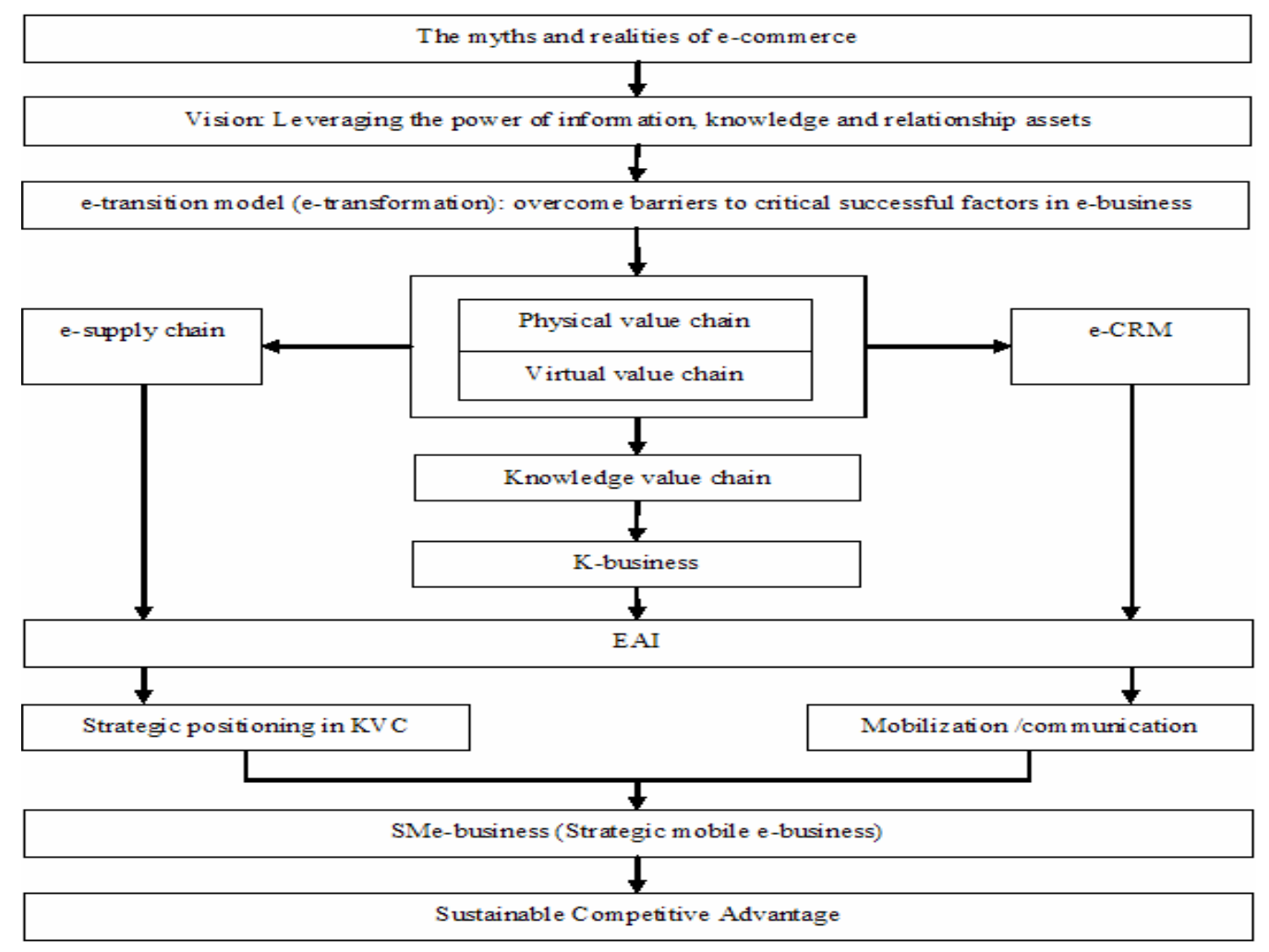

Figure 5-1: An integrated SMe-business model 